\title{
Perancangan dan Implementasi Aplikasi Verifikasi SNMPTN di Universitas Andalas Berbasis Android dan PHP MYSQL
}

\section{Design and Implementation of Android Base Entri Exam Application in Andalas University}

\author{
Deddy Prayama, Yuli Resmawati
}

Jurusan Teknologi Informasi, Politeknik Negeri Padang Kampus Limau Manis Padang 25163 Telp 0751-72590 Fax 0752-72576 Email : deddy@polinpdg.ac.id \& yulireswati@gmail.com

\begin{abstract}
Verification of entri exam as SNMPTN is an activity to confirm the data in schools which have been registered before at the University of Andalas. At the time of verification, the verification team still carries the paper to verify the data. Where as in times those are now many applications can facilitate the users. So to create verification application to facilitate the verification team to input data - verification of data and can be sent directly from the results of the verification data into the application server. This application only accessible for the verifier team, because this application an account to access it. Andalas University entri exam verification applications will be built using the Android programming language, PHP and MySql.
\end{abstract}

Keywords : Verification, Android, PHP, Mysql

\section{PENDAHULUAN}

Ilmu pengetahuan dan teknologi informasi selalu berkembang dan mengalami kemajuan, sesuai dengan perkembangan zaman dan perkembangan cara berfikir manusia. Salah satu pekembangan teknologi informasi saat sekarang ini adalah perangkat mobile khususnya Android. Android adalah sebuah sistem operasi untuk perangkat mobile berbasis linux yang dapat digunakan pada ponsel cerdas (smartphone), maupun komputer tablet (PC tablet). Android juga banyak meyediakan fitur - fitur yang dapat membantu penggunanya nantinya dalam mendapatkan informasi dengan cepat dan efisien seperti informasi dalam bidang pendidikan, bisnis, olahraga dan lainya.

Kelebihan android dari pada smartphone lain adalah bersifat open source code sehingga memudahkan para pengembang untuk melakukan atau menciptakan aplikasi ataupun memodifikasi fitur - fitur yang terdapat pada sistem operasi android.
Universitas Andalas merupakan salah satu perguruan tinggi negeri yang ada di wilayah Indonesia. Kampus dengan akreditasi A di Indonesia ini banyak menarik peminat yang ingin melanjutkan pendidikan ke jenjang yang lebih tinggi. Majalah Tempo pada tahun 2009 menempatkan Universitas Andalas di peringkat ke-14 atau posisi pertama di luar jawa dalam analisisnya terhadap kapasitas alumninya yang diserap oleh dunia usaha. Webometrics menobatkan Universitas Andalas sebagai

100 perguruan tinggi terbaik di ASEAN (peringkat ke -26) atau peringkat8 di Indonesia pada Januari 2011.

Untuk masuk Universitas Andalas ada berbagai jalur yang dapat dilalui seperti jalur SNMPTN, SBMPTN, Bidikmisi, Mandiri, dan lainya. Berdasarkan data dari website Universitas Andalas calon mahasiswa yang diterima melalui jalur SNMPTN 2015 sebanyak 2.379 orang, dengan perincian 1.519 reguler dan 860 Bidikmisi.

Setelah sekolah melakukan pendaftaran SNMPTN tehadap Universitas 
Andalas maka nantinya tim verifikasi (verifikator) dari Universitas Andalas akan melakukan verifikasi terhadap sekolah sekolah tersebut dengan membawa kertas verifikasi, dimana pada kertas verifikasi tersebut berisi dengan data sekolah dan pertanyaan - pertanyaan yang bersangkutan dengan data yang telah di inputkan sebelumnya oleh sekolah. Setelah melakukan verifikasi pada sekolah tim tersebut akan memberikan data pada admin untuk diinputkan kembali pada server yang telah ada.

Untuk itu dibutuhkan sebuah aplikasi yang dapat membantu tim verifikator nantinya dalam melakukan verifikasi SNMPTN terhadap sekolah yang sudah ditentukan, sehingga tim verifikator tidak perlu lagi untuk membawa kertas verifikasi. Aplikasi ini juga akan membantu nantinya admin untuk tidak perlu lagi menginputkan data kembali yang ada pada kertas verifikasi, karena dengan aplikasi ini nantinya pengguna (verifikator) dapat langsung menyimpan data tersebut pada server yang ada.

\section{METODOLOGI}

Penelitian ini terbagi menjadi beberapa tahap pengerjaan yang tertera sebagai berikut:

\section{Pengumpulan Data}

a. Metode Observasi

Pada tahapan ini data dikumpulkan dari sumber yaitu pihak LPTIK yang ada pada Universitas Andalas. Data yang akan diminta mengenai Tugas Akhir ini adalah sever yang akan digunakan untuk verifikasi.

b. Studi Pustaka

Yaitu dengan membaca, mempelajari dan memahami sumber buku cetak dan sumber buku lain yang berhubungan dengan masalah yang diangkatkan seperti buku android.

\section{Metode Pengembangan Sistem}

a. Analisis

Langkah ini merupakan tahap analisa yang akan dibutuhkan oleh aplikasi yang akan dirancang. Yaitu dengan cara menganalisis apa saja yang dibutuhkan pada aplikasi verifikasi SNMPTN.

b. Design

Proses design bertujuan untuk merancang atau membuat suatu aplikasi. Hal ini meliputi perancangan antarmuka aplikasi.

Tampilan untuk perancangan ini dapat berupa tampilan menu login dan menu utama.

c. Coding

Merupakan penerjemahan design sistem kedalam bahasa perograman. Pada tahapan ini difokuskan pada pembuatan aplikasi sesuai dengan design yang ada.

d. Implementasi

Tahapan ini merupakan tahapan akhir dari pembuatan sebuah aplikasi. Setelah melakukan analisa kebutuhan user, design, coding, maka sistem yang sudah jadi digunakan oleh user.

\section{Sistem Informasi}

Ada berbagai pendapat yang mendefinisikan pengertian sistem. Salah satunya menurut Lucas yang dikutip oleh Al-Bahra bin Ladjamudin(2005): "mendefinisikan sistem sebagai suatu komponen atau variable yang terorganisir, saling berinteraksi, saling bergantung, satu sama lain dan terpadu. Sebuah sistem mempunyai tujuan atau sasaran". ${ }^{[2]}$

Informasi merupakan data yang telah diperoleh menjadi bentuk yang lebih berarti dan berguna bagi penerimaan untuk mengambil keputusan masa kini maupun yang akan datang.

Sistem Informasi adalah suatu sistem didalam suatu organisasi yang mempertemukan kebutuhan pengolahan transaksi mendukung operasi, bersifat manajerial, dan kegiatan strategi dari suatu organisasi dan menyediakan pihak luar tertentu dengan laporan- laporan yang diperlukan. ${ }^{[2]}$

\section{Unified Modelling Language}

UML adalah bahasa grafis untuk mendukumentasi, menspesifikasikan, dan membangun sistem perangkat lunak. UML 
berorientasi objek, menerapkan banyak level abstraksi, tidak bergantung proses pengembangan, tidak bergantung bahasa dan teknologi, pemaduan beberapa notasi diberagam metodologi, usaha bersama dari banyak pihak, dukungan oleh kakas-kakas yang diintegrasikan lewat XML (XMI). Standar UML dikelola oleh OMG (Object Management group). ${ }^{[5]}$

UML diaplikasikan untuk maksud tertentu, biasanya antara lain sebagai berikut ${ }^{[6]}$ :

1. Merancang perangkat lunak.

2. Sarana komunikasi antara perangkat lunak dengan proses bisnis

3. Menjabarkan sistem secara rinci untuk analisa dan mencari apa yang diperlukan oleh sistem

4. Mendokumentasi sistem yang ada, proses - proses, dan organisasinya.

\section{Android}

Android merupakan sebuah sistem operasi untuk perangkat mobile berbasis linux yang mencakup sistem operasi, middleware dan aplikasi. Android menyediakan platform terbuka bagi para pengembang untuk menciptakan aplikasi mereka. Awalnya google Inc. Membeli Android Inc. Yang merupakan pendatang baru yang membuat peranti lunak untuk ponsel/smartphone. Kemudian untuk mengembangkan Android, dibentuklah Open Handset Alliance, konsorsium dari 34 perusahaan peranti keras, peranti lunak, dan telekomunikasi, termasuk Google, HTC, Intel, Motorola, Qualcomm, TMobile, dan Nvidia. ${ }^{[13]}$

Pada saat perilisan perdana Android, 5 November 2007, Android bersama Open Handset Alliance menyatakan mendukung pengembangan source pada perangkat mobile. Di lain pihak, Google merilis kode-kode Android di bawah lisensi Aphace, sebuah lisensi perangkat lunak dan open platform perangkat seluler.

Ada terdapat dua jenis distributor sistem operasi Android. Pertama yang mendapat dukungan penuh dari Google Mail Services (GMS) dan kedua adalah yang benar-benar bebas distribusinya tanpa dukungan langsung Google atau dikenal sebagai Open Handset Distibution (OHD).

Sekitar September 2007 Google mengenakan Nexus One, salah satu jenis smartphone yang menggunakan Android sebagai sistem operasinya. Telepon seluler ini diproduksi oleh HTC Corporation dan tersedia di pasaran pada 5 Januari 2010. Pada Desember 2008, diumumkan anggota baru yang bergabung dalam program kerja Android ARM Holdings, Atheros Communications, diproduksi oleh Asustek Computer Inc, Garmin Ltd, Softbank, Sony Ericsson, Toshiba Corp, dan Vodafone Group Plc. Seiring pembentukan Open Handset Alliance, OHA mengumumkan produk perdana mereka, Android, perangkat mobile merupakan modifikasi karnel Linux 2.6. sejak Android dirilis telah dilakukan berbagai pembaruan berupa perbaikan bug dan penambahan fitur baru.

Pada masa saat ini kebanyakan vendor-vendor smartphone sudah memproduksi smartphone berbasis Android. Hal ini karena Android itu adalah sistem operasi yang open source sehingga bebas didistribusikan dan dipakai oleh vendor manapun.

Tidak hanya menjadi sistem operasi di smartphone, saat ini Android menjadi pesaing utama Apple pada sistem operasi Table PC. Pesatnya pertumbuhan Android selain faktor yang disebutkan diatas adalah karena Android itu sendiri adalah platform yang sangat lengkap baik itu sistem operasinya, aplikasi dan tool pengembangan, market aplikasi android serta dukungan yang sangat tinggi dari komunitas Open Source di dunia, sehingga android terus berkembang pesat baik dari segi teknologi maupun dari segi jumlah device yang ada di dunia.

\section{Versi Android}

Adapun versi - versi android sebagai berikut $^{[9]}$ :

1. Android versi 1.1

Pada tanggal 9 Maret 2009, Google merilis android versi 1.1. Android versi 
ini dilengkapi dengan pembaruan estetis pada aplikasi, jam alarm, voice search (pencarian suara), pengiriman pesan dengan Gmail, dan pemberitahuan email.

2. Android versi 1.5 (Cupcake)

Pada pertengahan bulan Mei 2009, Google kembali merilis telepon seluler dengan menggunakan android dan SDK (Software Development Kit) dengan versi 1.5 yang disebut Cupcake. Terdapat beberapa pembaharuan termasuk juga penambahan beberapa fitur dalam seluler versi ini yakni kemampuan merekam dan menonton video dengan modus kamera, mengunggah video ke Youtube dan gambar ke Picasa langsung dari telepon, dukungan bluetooth A2DP, kemampuan terhubung secara otomatis ke headset bluetooth, animasi layar, dan keyboard pada layar yang dapat disesuaikan dengan sistem.

3. Android versi 1.6 (Donut)

Dirilis pada bulan September dengan menampilkan proses pencarian yang lebih baik dibanding sebelumnya, penggunaan baterai indikator dan kontrol applet VNP. Fitur lainya adalah galeri yang memungkinkan pengguna untuk memilih foto yang akan dihapus , kamera, camcorder dan galeri yang diintegrasikan CDMA/EVDO, 802.1x, VPN, Gesture, dan text - to - speech engine, kemampuan dial kontak, teknologi text to change speech.

4. Android versi 2.0/2.1 (Eclair)

Pada tanggal 3 Desember 2009 android kembali meluncurkan versi 2.0/2.1 atau eclair, perubahan yang dilakukan adalah pengoptimalan hardware peningkatan Google Maps 3.12, perubahan UI (user interface) dengan browser baru dan dukungan HTML5, daftar kontak yang baru, dukungan flash untuk kamera 3,2 MP, digital zoom, dan bluetooth 2.1.

5. Android versi 2.2 (Froyo : Frozen Yoghurt) Dirilis pada tanggal 20 Mei 2010, perubahan - perubahan umumnya terhadap versi - versi sebelumnya antara lain dukungan adobe flash 10.1, kecepatan kinerja dan aplikasi 2 sampai 5 kali lebih cepat, intergrasi V8 javascript engine yang dipakai google chrome yang mempercepat kemampuan rendering pada browser, pemasangan aplikasi dalam SD Card, kemampuan WiFi Hotspot portable, dan kemampuan auto update dalam aplikasi android market.

6. Android versi 2.3 (Gingerbread)

Pada tanggal 6 Desember 2010, android versi 2.3 atau yang disebut gingerbread diluncurkan. Perubahan - perubahan umum yang didapat dari android versi ini antara lain peningkatan kemampuan permainan (gaming), peningkatan fungsi copy paste, layar antar muka (user interface), didesain ulang, dukungan format video VP8 dan WebM, efek audio baru (reverb, equalization, headphone, virtualization, dan bass boost), dukungan kemampuan near filed communication (NFC), dukungan jumlah kamera lebih dari satu.

7. Android versi 3.0/3.1 (Honeycomb) Android honeycomb atau android versi 3.0/3.1 dirancang khusus untuk tablet. Android versi ini mendukung ukuran layar yang lebih besar. User interface pada honeycomb juga karena sudah didesain untuk tablet. Honeycomb juga mendukung multi prosesor dan juga akselerasi perangkat keras (hardware) untuk grafis. Tablet pertama dibuat dengan menjalankan honeycomb adalah Motorola Xoom. Perangkat tablet dengan platform android 3.0.

8. Android versi 4.0 (ICS: Ice Cream Sandwich) Dirilis pada tanggal 19 Oktober 2011, membawa fitur honeycomb untuk smartphone dan menambahkan fitur baru termasuk membuka kunci dengan pengenalan wajah, jaringan data pemantauan penggunaan dan kontrol, terpadu kontak jaringan sosial, perangkat tambahan fotografi, mencari email secara offline, dan berbagi informasi dengan menggunakan NFC. 
9. Android versi 4.1 (Jelly Bean)

Android jelly bean yang diluncurkan pada acara google I/O lalu membawa sejumlah keuntungan dan fitur baru. Penambahan baru diantaranya meningkatkan input keyboard, desain baru fitur pencarian, UI yang baru dan pencarian melalui voice search yang lebih cepat. Google now memberikan informasi yang tepat waktu. Salah satu kemampuanya adalah dapat mengetahui informasi cuaca, lalu-lintas, ataupun hasil pertandingan olahraga.

10. Android versi 4.4 (KitKat)

Android versi 4.4 (KitKet) API level 19. Google mengumumkan android KitKet (dinamai dengan izin Nestle dan Hershey) pada 3 September 2013. Dengan tanggal rilis 31 Oktober 2013. KitKet merupakan merk sebuah coklat yang dikeluarkan oleh Nestle. Rilis berikutnya setelah nama KitKat diperkirakan banyak pengamat akan diberi nomor 5.0 dan dinamai 'Key Lime Pie ${ }^{[8]}$.

\section{PHP}

PHP secara umum dikenal sebagai bahasa pemograman script - script yang membuat dokumen HTML secara on the fly yang dieksekusi di sever web, dokumen HTML yang dihasilkan dari suatu aplikasi bukan dokumen HTML yang dibuat dengan menggunakan editor teks atau editor HTML, dikenal juga sebagai bahasa pemrograman server web. ${ }^{[14]}$

Dengan menggunakan PHP maka maintenance suatu situs web menjadi lebih mudah. Proses update data dapat dilakukan dengan menggunakan aplikasi yang dibuat dengan menggunakan script PHP.

Beberapa kelebihan PHP dari bahasa pemrograman web, antara lain ${ }^{[1]}$ :

1. Bahasa pemrograman PHP adalah sebuah bahasa script yang tidak melakukan sebuah kompilasi dalam penggunaanya.

2. Web Server yang mendukung PHP dapat ditemukan dimana - mana dari mulai apache, IIS, Lighttpd, hingga Xitami dengan konfigurasi yang relatif mudah.

3. Dalam sisi pengembangan lebih mudah, karena banyaknya developer yang siap membantu dalam pengembangan

4. Dalam sisi pemahamanan, PHP adalah bahasa scripting yang paling mudah karena memiliki referensi yang banyak.

5. PHP adalah bahasa open source yang dapat digunakan di berbagai mesin (Linux, Unix, Macintosh, Windows) dan dapat dijalankan secara runtime melalui console serta juga dapat menjalankan perintah - perintah sistem.

\section{JSON}

JSON (javascript object notation) adalah salah satu struktur data javascript untuk mendefinisikan objek. Model struktur data JSON sekarang telah menjadi salah satu standar untuk pertukaran data yang ringan, yang sama populernya dengan XML. Ukuran file JSON lebih kecil dari pada file XML, karena pendefinisiannya yang lebih sederhana. Parsing data dari file JSON menjadi lebih cepat dan lebih mudah. Hal inilah yang membuat JSON secara defakto menjadi alternatif format untuk petukaran data. $^{[14]}$

Sesuai dengan namanya, maka JSON berawal dari bahasa pemograman javascript. Kemudahan dan fleksibelitasnya dalam mendefinisikan struktur data yang mirip XML tetapi lebih luwes lagi, menjadikan JSON sebagai alternatif format petukaran data.

JSON sekarang bukan hanya ada dalam javascript saja, tetapi sudah ada didukung pada banyak bahasa pemrograman, dengan demikian dapat menggunakan struktur data objek dengan JSON. Pada bahasa pemrograman, pengimplementasianya berbeda.

\section{JSON dalam PHP}

JSON telah menjadi format untuk pertukaran data yang universal, PHP termasuk bahasa pemrograman awal yang 
memberikan dukungan dengan menyediakan ekstension yang memungkinkan format data JSON dapat langsung diproses atau dihasilkan oleh PHP.

PHP akan mendapatkan data JSON berupa string yang kemudian akan diubah menjadi objek PHP atau sebaliknya untuk memberikan data kepada aplikasi lain yang membutuhkanya. Data JSON diterima oleh PHP sebagai string dan data string ini dalam PHP akan dikonversikan ke dalam struktur data asli (native) PHP. ${ }^{[14]}$

\section{MySQL}

MySql merupakan software RDBMS (Relasional Database Managament System) atau sever database yang dapat mengelola database dengan sangat cepat, dapat menampung data dalam jumlah besar, dapat diakses oleh banyak user (multi-user) dan dapat melakukan suatu proses secara sinkron atau berbarengan (multi-treaded) $^{[12]}$.

MySql memiliki sejumlah fitur sebagai berikut $^{[6]}$ :

\section{Multiplatfom}

MySql tersedia pada beberapa platform (Windows, Linux, Unix, dan lain - lain).

2. Andal, cepat, dan mudah digunakan MySql tergolong sebagai database server (server yang melayani permintaan terhadap database) yang andal, dapat menangani database yang besar dengan kecepatan tinggi, mendukung banyak sekali fungsi untuk mengakses database, dan sekaligus mudah untuk digunakan.

3. MySql dapat menangani sebuah table yang berukuran dalam terabyte (1 terabayte $=1024$ gigabyte). Namun, ukuran yang sesungguhnya sangat bergantung pada batasan sistem operasi.

4. Jaminan keamanan akses

MySql mendukung pengamanan database dengan berbagai kriteria pengaksesan. Sebagai gambaran, dimungkinkan untuk mengatur user tertentu agar bisa mengakses database yang bersifat rahasia (contohnya gaji pegawai), sedangkan user lain tidak dapat mengaksesnya.

5. Dukungan SQL

MySql mendukung perintah SQL (Structured Query Language). SQL merupakan standar dalam pengaksesan database relasional. Pengatahuan akan SQL akan memudahkan user dalam menggunakan MYSQL.

\section{Perancangan Sistem}

\section{Struktur Menu}

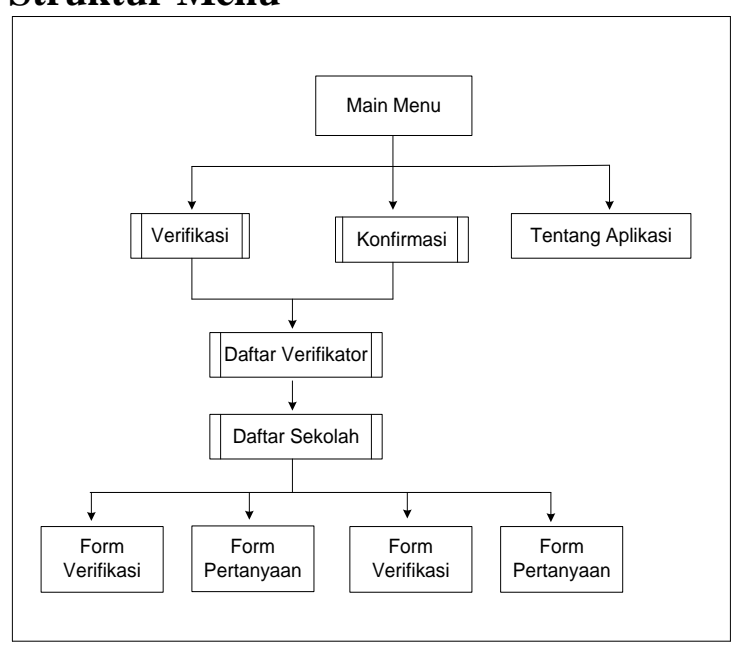

Gambar 1. Struktur Menu

Dari rancangan struktur menu pada gambar 1 diatas terdapat tiga pilihan main menu yaitu menu verifikasi, menu konfirmasi, dan menu tentang aplikasi. Pada menu verifikasi terdapat form daftar verifikator dan form daftar sekolah. Pada form daftar sekolah jika user memilih salah satu sekolah yang akan diverifikasi maka akan tampil form verifikasi dan pertanyaan.

Sedangkan pada menu konfirmasi juga terdapat form daftar verifikator dan form daftar sekolah. Pada form daftar sekolah jika user memilih sekolah yang sudah diverifikasi maka akan tampil data - data dari hasil verifikasi. Pada form verifikasi dan pertanyaan yang terdapat pada menu konfirmasi user dapat melakukan perubahan data jika terjadi kesalahan.

\section{Use Case Diagram}

Use Case mendefinisikan fitur - fitur yang terdapat dalam sistem. Pada use case 
diagram ini menunjukkan adanya interaksi antara aktor dengan sistem. Use case yang akan dirancang yaitu use case diagram untuk pengaksesan melalui perangkat android yaitu user dan pengaksesan dari server untuk mengelola data sekolah yaitu admin.

Pada use case diagram aplikasi verifikasi SNMPTN Universitas Andalas terdapat dua aktor yang berperan yaitu user dan admin. Aktor user (verifikator) merupakan aktor yang berperan pada aplikasi atau client dari verifikasi. Sedangkan aktor admin yaitu aktor yang berperan dalam mengelola server dari aplikasi.Adapun use case diagram untuk aplikasi verifikasi SNMPTN di Universitas Andalas berbasis android dapat dilihat pada gambar 2 dibawah ini :

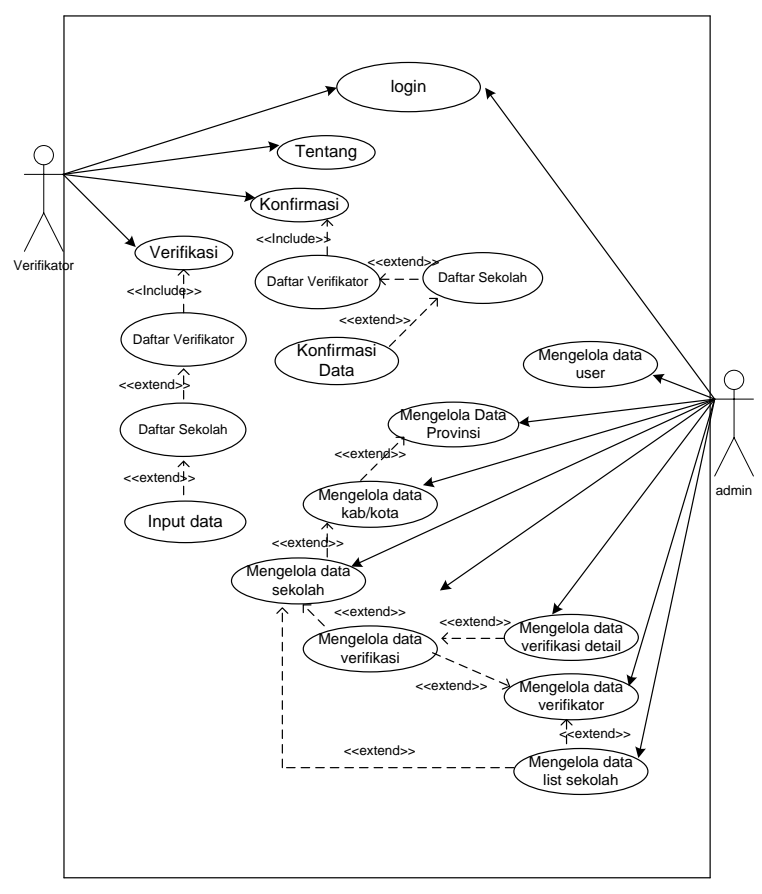

Gambar 2. Use Case Aplikasi

Deskripsi pendefinisian aktor yang terlibat pada use case diagram dapat dilihat pada tabel 1 :
Tabel 1. Deskripsi Aktor

\begin{tabular}{|c|c|c|}
\hline $\mathrm{No}$ & Aktor & Deskripsi \\
\hline 1 & verifikator & $\begin{array}{l}\text { Actor yang dapat melihat } \\
\text { dan menginputkan data } \\
\text { pada aplikasi. }\end{array}$ \\
\hline 2 & Admin & $\begin{array}{l}\text { Actor yang dapat } \\
\text { melihat, mengakses dan } \\
\text { mengelola data pada } \\
\text { server yang ada. }\end{array}$ \\
\hline
\end{tabular}

Tabel 2. Deskripsi Use Case

\begin{tabular}{|c|c|c|}
\hline No & Use Case & Deskripsi \\
\hline 1 & Login & $\begin{array}{l}\text { User dan admin login } \\
\text { untuk dapat melihat } \\
\text { dan melakukan } \\
\text { pengolahan data. }\end{array}$ \\
\hline 2 & Verifikasi & $\begin{array}{l}\text { User akan melakukan } \\
\text { penginputan data siswa, } \\
\text { dan data jawaban dari } \\
\text { pertanyaan } \\
\text { terdapat pada form } \\
\text { pertanyaan. }\end{array}$ \\
\hline 3 & Konfirmasi & $\begin{array}{l}\text { User dapat mengubah } \\
\text { data siswa, dan data } \\
\text { jawaban yang ada pada } \\
\text { form pertanyaan. }\end{array}$ \\
\hline 4 & Tentang & $\begin{array}{l}\text { User dapat melihat } \\
\text { tentang aplikasi. }\end{array}$ \\
\hline 5 & $\begin{array}{l}\text { Mengelola data } \\
\text { user }\end{array}$ & $\begin{array}{l}\text { Admin dapat mengelola } \\
\text { data dari menghapus, } \\
\text { mengubah, } \\
\text { menambah data user } \\
\text { pada server. }\end{array}$ \\
\hline 6 & $\begin{array}{l}\text { Mengelola data } \\
\text { provinsi }\end{array}$ & $\begin{array}{l}\text { Admin dapat mengelola } \\
\text { data dari menghapus, } \\
\text { mengubah, dan } \\
\text { menambah data } \\
\text { provinsi pada server. }\end{array}$ \\
\hline 7 & $\begin{array}{l}\text { Mengelola data } \\
\text { kabupaten/kota }\end{array}$ & $\begin{array}{lr}\text { Admin dapat mengelola } \\
\text { data dari menghapus, } \\
\text { mengubah, } \\
\text { menambah } & \text { dan } \\
\text { kabupaten atau kota } \\
\text { pada server. }\end{array}$ \\
\hline 8 & $\begin{array}{l}\text { Mengelola data } \\
\text { sekolah }\end{array}$ & $\begin{array}{l}\text { Admin dapat mengelola } \\
\text { data dari menghapus, } \\
\text { mengubah, dan } \\
\text { menambah data sekolah } \\
\text { pada server. }\end{array}$ \\
\hline 9 & $\begin{array}{l}\text { Mengelola data } \\
\text { verifikator }\end{array}$ & $\begin{array}{l}\text { Admin dapat mengelola } \\
\text { data dari menghapus, } \\
\text { mengubah, dan } \\
\text { menambah } \\
\text { verifikator pada server. }\end{array}$ \\
\hline 10 & $\begin{array}{l}\text { Mengelola data } \\
\text { list sekolah }\end{array}$ & $\begin{array}{l}\text { Admin dapat mengelola } \\
\text { data dari menghapus, } \\
\text { mengubah, dan } \\
\text { menambah data list } \\
\text { sekolah pada server. }\end{array}$ \\
\hline
\end{tabular}




\begin{tabular}{|c|c|c|}
\hline No & Use Case & Deskripsi \\
\hline 11 & $\begin{array}{l}\text { Mengelola data } \\
\text { verifikasi }\end{array}$ & \begin{tabular}{l}
\multicolumn{2}{c}{ Admin dapat mengelola } \\
data dari menghapus, \\
mengubah, dan \\
menambah data \\
verifikasi pada server.
\end{tabular} \\
\hline 12 & $\begin{array}{l}\text { Mengelola data } \\
\text { verifikasi detail }\end{array}$ & $\begin{array}{l}\text { Admin dapat mengelola } \\
\text { data dari menghapus, } \\
\text { mengubah, } \\
\text { menambah } \\
\text { verifikasi detail pada } \\
\text { server. }\end{array}$ \\
\hline
\end{tabular}

\section{Rancangan Activity Diagram}

Activity diagram menjelaskan bagaimana alur aplikasi dari awal sampai selesai. Pada aplikasi ini terdapat dua activity diagram yaitu activity diagram user dan admin. Pada diagram activity ini user (verifikator) akan login terlebih dahulu sebelum dapat masuk pada aplikasi. Berikut tampilan diagram activity user dapat dilihat pada Gambar 3 berikut ini :

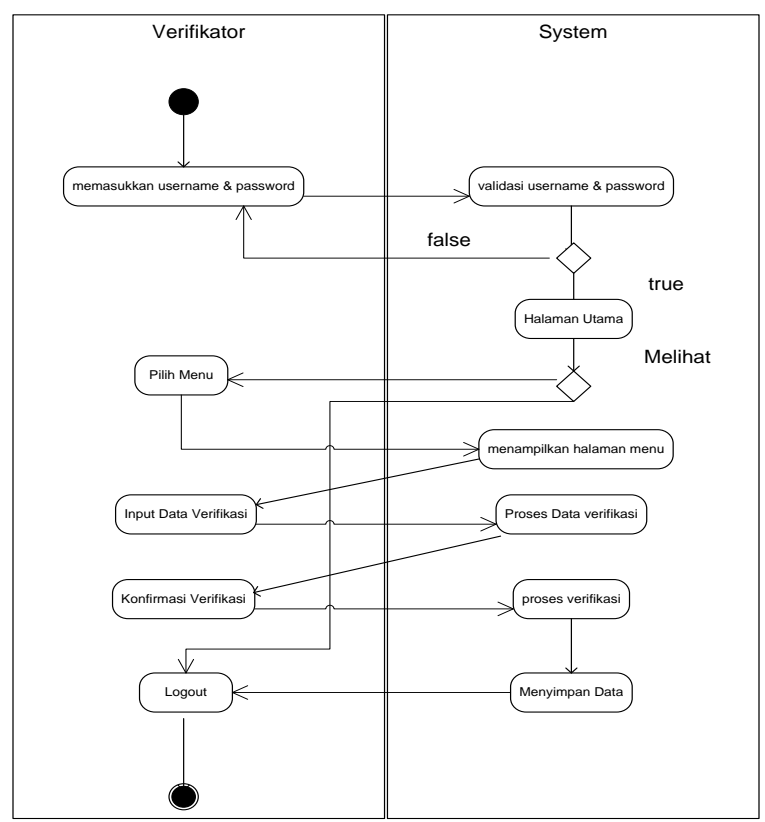

Gambar 3. Activity Diagram

\section{Rancangan Class Diagram}

Class Diagram merupakan suatu rancangan yang dapat menunjukkan hubungan antara satu kelas dengan kelas lainya dalam sistem yang sedang dirancang. Class diagram juga menunjukkan struktur kelas - kelas pada sistem. Berikut tampilan diagram class diagram dapat dilihat pada Gambar 4 berikut ini :

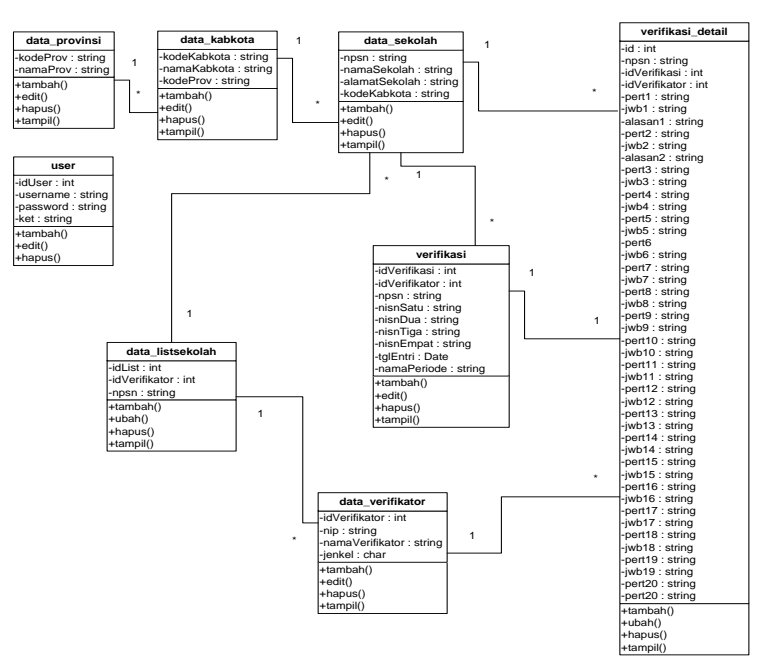

Gambar 4. Class Diagram

\section{Rancangan interface aplikasi}

Berikut ini ditampilkan rancangan rancangan interface aplikasi yang dirancang ;
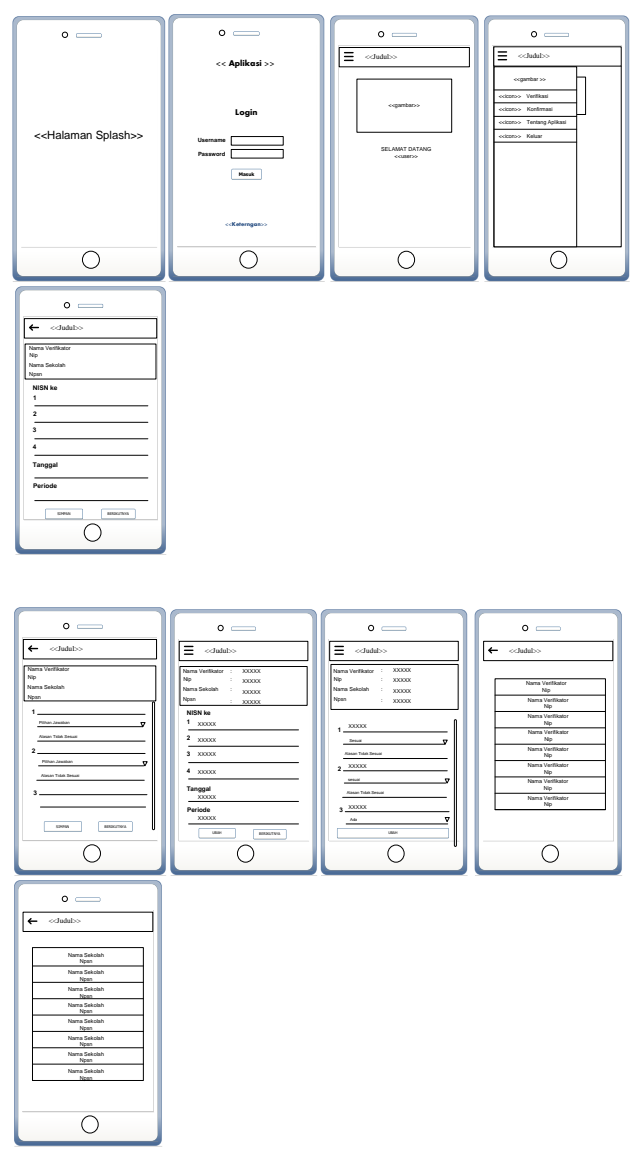

Gambar 5. Rancangan interface 


\section{PEMBAHASAN}

Berikut ini adalah tampilan aplikasi pada saat diimplementasikan pada smartphone android Kit Kat :
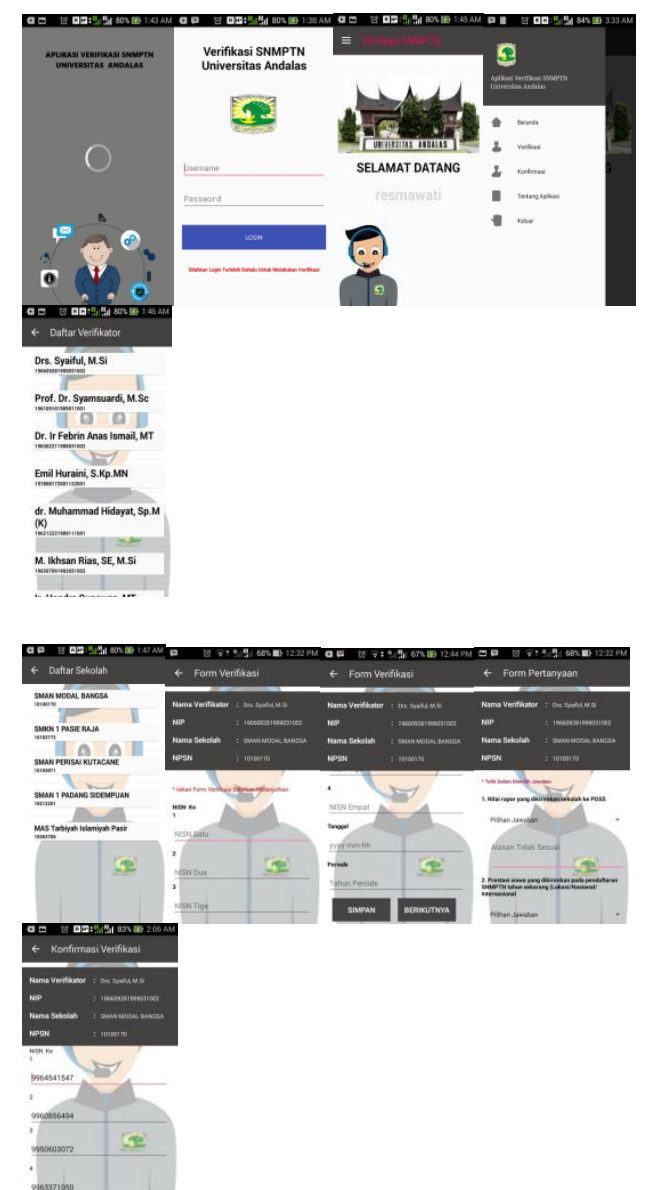

Gambar 6. Tampilan Aplikasi di smartphone

\section{Pengujian}

Berikut ini adalah tabel hasil pengujian aplikasi pada smartphone android :

Tabel 2. Pengujian aplikasi

\begin{tabular}{|c|c|c|c|c|}
\hline NO & $\begin{array}{l}\text { User Interface } \\
\text { Yang Diuji }\end{array}$ & $\begin{array}{l}\text { Skenario } \\
\text { Pengujian }\end{array}$ & $\begin{array}{l}\text { Hasil Yang } \\
\text { Diharapkan }\end{array}$ & $\begin{array}{l}\text { Hasil } \\
\text { Uji }\end{array}$ \\
\hline 1 & Login & $\begin{array}{l}\text { User (verifikator) } \\
\text { input Username dan } \\
\text { Password }\end{array}$ & $\begin{array}{l}\text { Tampil pada Form } \\
\text { yang disediakan }\end{array}$ & Sesuai \\
\hline 2 & $\begin{array}{l}\text { Halaman Menu } \\
\text { Utama }\end{array}$ & $\begin{array}{l}\text { User (verifikator) } \\
\text { menekan tombol } \\
\text { menu pada kiri atas } \\
\text { layar atau usap } \\
\text { layaar dari tepi kiri } \\
\text { ke tengah layar }\end{array}$ & $\begin{array}{l}\text { Tampil menu } \\
\text { beranda, } \\
\text { verifikasi, } \\
\text { konfirmasi, } \\
\text { tentang aplikasi } \\
\text { dan keluar }\end{array}$ & sesuai \\
\hline 3 & $\begin{array}{l}\text { Halaman menu } \\
\text { verifikasi }\end{array}$ & $\begin{array}{l}\text { User (verifikator) } \\
\text { menekan menu } \\
\text { verifikasi pada menu } \\
\text { utamas. }\end{array}$ & $\begin{array}{lr}\text { Tampil } & \text { halaman } \\
\text { daftar verifikator } \\
\text { yang terdiri dari } \\
\text { nama verifikator } \\
\text { dan nip }\end{array}$ & sesuai \\
\hline 4 & $\begin{array}{l}\text { Halaman daftar } \\
\text { verifikator }\end{array}$ & $\begin{array}{lr}\text { User } & \text { (verifikator) } \\
\text { menekan } & \text { salah satu } \\
\text { dari rritar } & \text { daftar } \\
\text { verifikator }\end{array}$ & $\begin{array}{l}\text { Tampil halaman } \\
\text { daftar sekolah } \\
\text { yang terdiri dari } \\
\text { nama sekolah dan } \\
\text { npsn }\end{array}$ & Sesuai \\
\hline 5 & Halaman daftar & (verifikator) & Tampil & sesuai \\
\hline
\end{tabular}

\begin{tabular}{|c|c|c|c|c|}
\hline NO & $\begin{array}{l}\text { User Interface } \\
\text { Yang Diuji }\end{array}$ & $\begin{array}{l}\text { Skenario } \\
\text { Pengujian }\end{array}$ & $\begin{array}{l}\text { Hasil Yang } \\
\text { Diharapkan }\end{array}$ & $\begin{array}{l}\text { Hasil } \\
\text { Uji }\end{array}$ \\
\hline & sekolah & $\begin{array}{l}\text { menekan salah satu } \\
\text { dari daftar sekolah }\end{array}$ & verifikasi & \\
\hline 6 & Form verifikasi & $\begin{array}{l}\text { User (verifikator) } \\
\text { menambahkan data } \\
\text { pada form verifikasi }\end{array}$ & $\begin{array}{l}\text { Tampil pesan pada } \\
\text { saat data disimpan } \\
\text { ke server }\end{array}$ & Sesuai \\
\hline 7 & $\begin{array}{l}\text { Form } \\
\text { pertanyaan }\end{array}$ & $\begin{array}{l}\text { User (verifikator) } \\
\text { menambahkan data } \\
\text { pada form } \\
\text { pertanyaan }\end{array}$ & $\begin{array}{l}\text { Tampil pesan pada } \\
\text { saat data disimpan } \\
\text { ke server }\end{array}$ & Sesuai \\
\hline 8 & $\begin{array}{l}\text { Halaman menu } \\
\text { konfirmasi }\end{array}$ & $\begin{array}{l}\text { User (verifikator) } \\
\text { menekan menu } \\
\text { verifikasi pada menu } \\
\text { utamas. }\end{array}$ & $\begin{array}{l}\text { Tampil halaman } \\
\text { daftar verifikator } \\
\text { yang terdiri dari } \\
\text { nama verifikator } \\
\text { dan nip }\end{array}$ & sesuai \\
\hline 9 & $\begin{array}{l}\text { konfirmasi } \\
\text { verifikasi }\end{array}$ & $\begin{array}{l}\text { User (verifikator) } \\
\text { mengubah data pada } \\
\text { konfirmasi verifikasi }\end{array}$ & $\begin{array}{l}\text { Tampil pesan pada } \\
\text { saat data disimpan } \\
\text { ke server }\end{array}$ & Sesuai \\
\hline 12 & $\begin{array}{l}\text { konfirmasi } \\
\text { pertanyaan }\end{array}$ & $\begin{array}{l}\text { User (verifikator) } \\
\text { mengubah data pada } \\
\text { konfirmasi } \\
\text { pertanyaan }\end{array}$ & $\begin{array}{l}\text { Tampil pesan pada } \\
\text { saat data disimpan } \\
\text { ke server }\end{array}$ & Sesuai \\
\hline 13 & $\begin{array}{l}\text { Menampilkan } \\
\text { tentang dari } \\
\text { aplikasi }\end{array}$ & $\begin{array}{ll}\text { User (verifikator) } \\
\text { memilih } \\
\text { tentang dari menu } \\
\text { utama }\end{array}$ & $\begin{array}{l}\text { Tampil halaman } \\
\text { tentang aplikasi }\end{array}$ & Sesuai \\
\hline 14 & Menu Keluar & $\begin{array}{l}\text { User (verifikator) } \\
\text { akan menekan } \\
\text { tombol keluar }\end{array}$ & $\begin{array}{lr}\text { User } & \text { (verifikator) } \\
\text { akan } & \text { menekan } \\
\text { tombol } & \text { keluar } \\
\text { untuk } & \text { menutup } \\
\text { aplikasi } & \end{array}$ & Sesuai \\
\hline
\end{tabular}

Untuk lebih terujinya aplikasi yang dirancang, maka aplikasi tersebut juga diujicoba pada beberapa smartphone android yang beredar dipasaran, berikut ini adalah tabel hasil pengujiannya.

Tabel 3. Pengujian di beberapa

\begin{tabular}{|c|c|c|c|c|c|}
\hline No & Nam & Ukuran & Versi & Hasil p & zujian \\
\hline & $\begin{array}{c}\text { a } \\
\text { Smart } \\
\text { phon } \\
e \\
\end{array}$ & layar & android & Tampilan & $\begin{array}{c}\text { Hasil } \\
\text { Uji }\end{array}$ \\
\hline 1 & $\begin{array}{l}\text { Sams } \\
\text { ung } \\
\text { galax } \\
\text { y } \\
\text { grand } \\
\text { prime }\end{array}$ & 5 inci & $\begin{array}{l}4.4 .4 \\
\text { (Kitkat) }\end{array}$ & $\begin{array}{l}\text { Tampilan } \\
\text { aplikasi } \\
\text { sesuai }\end{array}$ & $\begin{array}{l}\text { Aplikasi } \\
\text { berjalan } \\
\text { dengan } \\
\text { baik }\end{array}$ \\
\hline 2 & $\begin{array}{l}\text { Oppo } \\
\text { neo } 5\end{array}$ & 4.5 inci & $\begin{array}{l}4.4 .2 \\
\text { (Kitkat) }\end{array}$ & $\begin{array}{l}\text { Tampilan } \\
\text { aplikasi } \\
\text { sesuai }\end{array}$ & $\begin{array}{l}\text { Aplikasi } \\
\text { berjalan } \\
\text { dengan } \\
\text { baik }\end{array}$ \\
\hline 3 & Asus & 5 inci & $\begin{array}{l}5.0 \\
\text { (Lollipop) }\end{array}$ & $\begin{array}{l}\text { Tampilan } \\
\text { aplikasi } \\
\text { kurang } \\
\text { sesuai }\end{array}$ & $\begin{array}{l}\text { Aplikasi } \\
\text { berjalan } \\
\text { dengan } \\
\text { baik }\end{array}$ \\
\hline 4 & $\begin{array}{l}\text { Asus } \\
\text { Zenfo } \\
\mathrm{n} \mathrm{c}\end{array}$ & 4.5 inci & $\begin{array}{l}4.4 .2 \\
\text { (Kitkat) }\end{array}$ & $\begin{array}{l}\text { Tampilan } \\
\text { aplikasi } \\
\text { sesuai }\end{array}$ & $\begin{array}{l}\text { Aplikasi } \\
\text { berjalan } \\
\text { dengan } \\
\text { baik }\end{array}$ \\
\hline 5 & $\begin{array}{l}\text { Sony } \\
\text { Xperi } \\
\text { a z5 } \\
\text { Dual }\end{array}$ & 5.2 inci & $\begin{array}{l}6.0 .1 \\
\text { (Marshmal } \\
\text { low) }\end{array}$ & $\begin{array}{l}\text { Tampilan } \\
\text { aplikasi } \\
\text { kurang } \\
\text { sesuai }\end{array}$ & $\begin{array}{l}\text { Aplikasi } \\
\text { berjalan } \\
\text { dengan } \\
\text { baik }\end{array}$ \\
\hline
\end{tabular}

\section{Analisa Pengujian}

Setelah melakukan pengujian secara menyeluruh terhadap aplikasi informasi Verifikasi SNMPTN Universitas Andalas, maka dapat disimpulkan:

1. Hasil pengujian telah sesuai dengan input masukan user. 
2. Dari hasil pengujian, data yang di simpan pada server juga telah sesuai apa yang dimasukkan di aplikasi android.

3. Dari pengujian aplikasi, aplikasi berjalan dengan baik pada smartphone yang sistem operasinya android minimal versi 5.0 (lollipop), sedangkan dijalankan pada smartphone yang sistem operasinya android versi 6.0 (marshmallow) tampilan aplikasi kurang sesuai.

4. Dari pengujian aplikasi, tampilan aplikasi berjalan dengan baik jika di jalankan dengan smartphone mempunyai ukuran layar 4.5 inci.

\section{SIMPULAN}

Setelah dilakukan implementasi dan analisa makan dapat diambil beberapa kesimpulan sebagai berikut :

1. Aplikasi Verifikasi SNMPTN Universitas Andalas memiliki server yang digunakan untuk mengelola data verifikasi .

2. Aplikasi Verifikasi SNMPTN Universitas Andalas telah dapat memudahkan user (verifikator) dalam melakukan penambahan data sekolah menengah atas (SMA) umum dan sederajat pada verifikasi.

3. Aplikasi Verifikasi SNMPTN Universitas Andalas dapat menampilkan data sekolah sekolah menengah atas (SMA) umum dan sederajat yang akan diverifikasi.

4. Aplikasi Verifikasi SNMPTN Universitas Andalas dapat menyimpan hasil data sekolah menengah atas (SMA) umum dan sederajat yang telah diverifikasi pada server yang telah disediakan.

5. Aplikasi Verifikasi SNMPTN Universitas Andalas kurang efektif, karena tidak adanya data sebagai pembanding bagi user (verifikator) pada saat verifikasi dilakukan.

\section{DAFTAR PUSTAKA}

[1] Aditya, Alan Nur. (2011) : Jago PHP dan MYSQL. Jakarta: Dunia Komputer.

[2] Bin, Ladjamudin, Al-bahra. (2005) : Analisis dan Desain Sistem Informasi. Yogyakarta. Graha Ilmu.

[3] Enterprise Jubilee. (2015) : Mengenal Dasar - Dasar Pemrograman Android. Jakarta: PT Elex Media Komputindo.

[4] Newman, Frans. (2001) : Pemrograman Client / Server Dengan ASP. Jakarta: PT Elex Media Komputindo

[5] Hariyanto, Bambang. (2004) : Rekayasa sistem Berorientasi Objek.Bandung: Informatika.

[6] Kadir, Abdul. (2008) : Belajar Database Menggunakan Mysql. Yogyakarta: Andi.

[7] Kusuma, Aditya Candra. (2013) : Perancangan Aplikasi Mobile Edukatif 'Belajar Chord Piano Untuk Pemula' Berbasis Android. Amikom Yogyakarta : Thesis.

[8] Lengkong, Hendra Nugraha (2015) : Perancangan Penunjuk Rute Pada Kendaraan Pribadi Menggunakan Aplikasi Mobile GIS Berbasis Android Yang Terintegrasi Pada Google Maps, E- Journal Teknik Elektro dan Komputer, 21

[9] Murya, Yosef. (2014) : Pemrograman Android Black Box. Yogyakarta: Jasakom.

[10]Pudjo, Widodo Prabowo dan Herlawati. (2011) : menggunakan UML (Unified Modeling Language). Bandung: Informatika.

[11]Prasetyo, Didik Dwi. (2003) : Aplikasi Database Client/Server menggunakan 
Delphi dan MYSQL. Yogyakarta: PT Elex Media Komputindo.

[12]Raharjo, Budi. (2011) : Belajar Ototidak Membuat Database Menggunakan MYSQL. Bandung: Informatika.

[13] Safaat, H Nazruddin. (2014) : Android Pemograman Aplikasi Mobile Smartphone dan Table PC Berbasis Android. Bandung: Informatika.

[14]Sidik Betha. 2012. Pemrograman $W E B$ dengan PHP. Bandung: Informatika.

[15]Winarno Edy, All Zaki, SmitDev Community. (2012) : Hacking dan Programming dengan Android SDK untuk Advanced. Jakarta: PT Elex Media Komputindo.

[16]http://www.sir.stikom.edu (27 July 2016) 